\title{
PECULIARITIES OF THE EFFECTS OF BILE ACIDS ON ATPASE ACTIVITY OF THE COLON MUCOSA IN PATIENTS WITH OVERWEIGHT AND IRRITABLE BOWEL SYNDROME
}

DOI: 10.36740/WLek202003133

\author{
Iryna M. Ferents' ${ }^{1}$, Solomiia V. Bychkova ${ }^{2}$, Mykola A. Bychkov ${ }^{1}$ \\ 'DANYLO HALYTSKYLVIV NATIONAL MEDICAL UNIVERSITY, LVIV, UKRAINE \\ IIVAN FRANKO NATIONAL UNIVERSITY, LVIV, UKRAINE
}

\begin{abstract}
The aim is to investigate the effect of bile acids on the ATPase activity of the colon mucosa in patients with overweight and irritable bowel syndrome (IBS).

Materials and methods: Completely examined 12 patients with IBS and overweight. We estimated the ATPase activity of colon mucous of the patients with IBSspectrophotometrically by determined the content of orthophosphate that was released after ATP hydrolysis. We studied the effect of 3-sulphate of taurolitocholate (TLC-S) on specific activities of $\mathrm{Na}^{+} /$ $\mathrm{K}^{+}$-ATPase, $\mathrm{Ca}^{2+}$-ATPase of endoplasmatic reticulum (EPR), $\mathrm{Ca}^{2+}$-ATPase of plasmatic membrane (PM) and basal $\mathrm{Mg}^{2+}$-ATPase of postmitochondrial subcellular fraction of colon mucous of the patients with IBS.

Results: We establishedthe specific activities of $\mathrm{Na}^{+} / \mathrm{K}^{+}$-ATPase, $\mathrm{Ca}^{2+}$-ATPase of EPR, (a ${ }^{2+}$-ATPase of PM and basal $\mathrm{Mg}^{2+}$-ATPase. Therewere(6.06 \pm 1.61$),(5.88 \pm 1.19),(8.86$ $\pm 1.56)(6.44 \pm 2.02) \mu \mathrm{mol} \mathrm{P}_{\mathrm{i}} / \mathrm{mg}$ protein per hour, respectively. TLC-S $(50 \mu \mathrm{M})$ did not causedany change of $\mathrm{Na}^{+} / \mathrm{K}^{+}$-ATPase, as well as $\mathrm{Ca}^{2+}$-ATPasesactivities, but statistically significant increased activity of $\mathrm{Mg}^{2+}$-ATPase of postmitochondrial subcellular fraction of colon mucous of the patients with IBS by 4 fold.

Conclusions: TLC-S increased basal $\mathrm{Mg}^{2+}-$ ATPase in the postmitochondrial fraction of colon mucous of the patients with overweight and IBS, but had no effect on $\mathrm{Na}^{+} / \mathrm{K}^{+}-\mathrm{ATPase}$ and $\mathrm{Ca}^{2+}$-ATPases activities. It has been suggested that activation of basal $\mathrm{Mg}^{2+}$-ATPase under by TLC-S may indicates the role of the endo-lysosomal system of epitheliocytes of colon mucous in developing of pathology IBS.
\end{abstract}

KEY WORDS: irritable bowel syndrome, overweight, ATPase, bile acids

Wiad Lek. 2020;73(3):574-577

\section{INTRODUCTION}

Increased food intake and a reduction in energy expenditure are responsible for the increase in excess body weight and subsequent obesity. Today, according to the World Health Organization, over one billion people are overweight on the planet. In Ukraine, approximately one third of the population has excess body weight [1]. Obesity is the cause of various somatic diseases, in particular, the gastrointestinal tract, including gastroduodenitis with nausea and functional vomiting and irritable bowel syndrome (IBS), which is most often associated with restrictive eating behavior. According to various authors, the combination of obesity with dyskinesias of the colon with constipation, diverticular disease, colon polyposis was diagnosed, respectively, at 36,$28 ; 28.0$ and $10.0 \%$ of patients. Other researchers have found that in obese individuals an association with functional constipation occurred in $24.0 \%$ of cases, and obesity was observed in $60.0 \%$ of patients with constipation [2].

Obesity also develops against a backdrop of stress, serving as an indicator of psycho-emotional maladaptation and overcoming difficult life situations that are inhibited by excessive eating. In addition, excess body weight can act as a factor that prevents pleasure from life, and the latter phenomenon can be a factor that affects eating disorders, which in turn can contribute to the appearance of constipation, abdominal pain, changes in the sensitivity of serotonin receptors of the intestinal wall [2].

Obesity and a high body mass index have been shown to be significant risk factors for the development of IBS, in addition to insufficient amount of fiber in the diet, stress, inflammation, genetic predisposition [3]. Today, IBS is one of the most common diseases of the gastrointestinal tract, and obesity is an urgent problem of endocrinology [4]. IBS according to Rome Criteria IV is defined as a chronic functional bowel disorder characterized by recurrent abdominal pain, which occurs and continues at least once a week for the last three months, associated with bowel movements, changes in frequency and consistency of the stool [5].

An important factor in improving the diagnosis of IBS is to take into account the pathogenetic factors of the disease. In recent decades, perceptions of the pathogenesis of IBS have changed significantly. Previously, IBS was considered exclusively as a psychosomatic disease, and in almost all patients it was associated with the influence of psycho-emotional factors, but today the multifactorial development of IBS is obvious. Food allergies, stress, intes- 
tinal infections, hereditary predisposition, malabsorption, and disorders of bile acid metabolism are the major triggers for the development of IBS [6]. Bile acids are amphipathic, detergent molecules synthesized by the liver that facilitate the absorption of lipids and fat soluble vitamins in the small intestine. Lithocholic and deoxycholic acids are the main bile acids present in the colon and feces. Henodeoxycholic and deoxycholic acids are known secretory bile acids. Increased excretion of feces and changes in the proportion of various bile acids in the feces characterize malabsorption of bile acids, which leads to diarrhea or IBS with diarrhea, which are associated with increased secretion of water and mucus in the colon, motility of the colon and membrane permeability. Bile malabsorption is known in $10-33 \%$ of patients with IBS with diarrhea or functional diarrhea [7].

However, the mechanisms of the link between metabolic regulation of bile acids and the pathogenesis of IBS remain unclear. Thus, studies that help identify specific pathogenetic mechanisms for the development of IBS are relevant.

\section{THE AIM}

The aim is to investigate the effect of bile acids on the ATPase activity of the colon mucosa in patients with overweight and irritable bowel syndrome.

\section{MATERIALS AND METHODS}

All procedures with patient were performed in accordance with the informed consent of the patient "International Convention for Working with Animals" under approval of the Bioethics Committee of DanyloHalytskyLviv National Medical University, protocol No2, 15/02, 2016.

Complex examination of 12 patients with IBS and excess body weight (mean age $-32,7 \pm 1,5$ years). The diagnosis of IBS was established according to Rome criteria IV [5] in the presence of recurrent abdominal pain, which was observed at least 1 day per week for the last 3 months and when there were two or more of the following symptoms: abdominal pain associated with bowel movements, pain accompanied by changing the frequency of stools or form of feces. For diagnosisof inflammatory bowel pathology, CITO TEST Calprotectin-Lactoferrin (Pharmasco) was performed. Wepayed attention to the absence of symptoms of anxiety: fever, impurities of blood in the stool, intestinal disorders, weight loss for a short period of time, anemia, leukocytosis, acceleration of erythrocyte sedimentation rate. All patients performed measurements of height and body weight. Body mass index was calculated by the Kattle formula. According to the obtained indicators, we established the presence of excess body weight.

Isolation of subcellular postmitochondrial fraction of the patients' colon mucous. Tissue samples were collected from patients colon during colonoscopy. Fresh samples were washed by medium $\mathrm{A}(\mathrm{mM})$ : sucrose -250 , ethylene glycol tetraacetic acid (EGTA) - 1, HEPES - 10; $\mathrm{KH}_{2} \mathrm{PO}_{4}-1$; $\mathrm{pH}$ 7.2. Then these samples were homogenized with glassglass homogenizer at $300 \mathrm{rev} / \mathrm{min}$ for $10 \mathrm{~min}$ at $0-2{ }^{\circ} \mathrm{C}$.
The homogenate was centrifuged for $10 \mathrm{~min}$ at $3.000 \mathrm{~g}$ using Jouan MR 1812 centrifuge (Jouan, France) to precipitate nuclei, large cells fragments, and undestroyed cells while mitochondria remained in the supernatant 1 . Next centrifugation of this supernatant 1 carried out for $10 \mathrm{~min}$ at $8.500 \mathrm{~g}\left(0-2^{\circ} \mathrm{C}\right)$. After mitochondria sedimentation, supernatant 2 was used for while ATPase activity assay. To prove a membranes presence in the post-mitochondrial fraction it was sediment for $20 \mathrm{~min}$ at $15.000 \mathrm{~g}$.

Assay of ATPase activity. ATPase activity was determined according to the content of orthophosphate that was released after ATP hydrolysis [8,9]. At the beginning of the experiment $200 \mu$ lof post-mitochondrial subcellular fraction of patients' colon mucous was transferred to a standard incubation medium containing $(\mathrm{mM})$ $\mathrm{NaCI}$ - 50.0; KCI - 100.0; Tris-HCI - 20.0; $\mathrm{MgCI}_{2}-3.0$; $\mathrm{CaCI}_{2}-0.01 ; \mathrm{pH} 7.4$ at $37^{\circ} \mathrm{C}$. The reaction was started by adding 3 mMATP(Sigma, USA). Samples were incubated for 15 minat $37^{\circ} \mathrm{C}$ withmoderateshakingin a water bath. Before theend ofincubation $0.4 \mathrm{ml}$ of mediumwas takenfor the determination ofprotein content by Lowry [10]. Reactionwas stopped byadding $5 \mathrm{ml}$ of $10 \%$ trichloroaceticacid to samples and incubating themfor 30 minfollowed by 10 min centrifugationat 1600 g. Supernatant obtainedwas usedto determine thecontentofinorganic phosphorusby the spectrophotometric method ofFiske-Subbarow[11]. We used TLC-S(Sigma, USA) at concentration $50 \mu \mathrm{mol} / \mathrm{L}$ for estimating their effect on ATPase activity.

Calculation of ATPase activity. The total ATPase activity of post-mitochondrial fraction of colon mucous was calculated by the difference of inorganic phosphorus in the medias with different composition (supplemented with TLC-S - "experiment" or not supplemented - "control") expressed as micromoles of inorganic phosphorus equivalent to $1 \mathrm{mg}$ of protein per $1 \mathrm{~h}$. Specific $\mathrm{Na}^{+} / \mathrm{K}^{+}$-ATPase activity was calculated as difference of inorganic phosphorus content in medium with or without ouabain ( $1 \mathrm{mM})$. For thedetermination of $\mathrm{Ca}^{2+} / \mathrm{Mg}^{2+}$-ATPase activity, the differencebetween the totalCa ${ }^{2+} / \mathrm{Mg}^{2+}$-andNa ${ }^{+} / \mathrm{K}^{+}$-ATPaseactivity was quantified.Thapsigargin was used to calculate SERCA contribution into the total $\mathrm{Ca}^{2+} / \mathrm{Mg}^{2+}$-ATPase activity. Specific basal $\mathrm{Mg}^{2+}$-ATPaseactivitywas determinedin incubationmediumthatcontained 1 mMEGTA and lackedouabain. In allexperiments, incubation mediumwas as a controlforthe enzymaticATP hydrolysis.

Data analysis. The significance of differences between experimental groups was calculated using Wilcoxon-Mann-Whitney, when a data distributions were not normal. $\mathrm{P} \leq 0.05$ was considered to be statistically significant.

\section{RESULTS}

It was found that $\mathrm{Na}^{+} / \mathrm{K}^{+}$-ATPase activity of subcellular fraction of colon mucous ranged from 2.32 to 15.76 and averaged $(6.06 \pm 1.61) \mu \mathrm{mol} \mathrm{Pi} / \mathrm{mg}$ protein per hour. TLC-S caused ranging of $\mathrm{Na}^{+} / \mathrm{K}^{+}$-ATPase activity from 0.74 to 13.99 and averaged $(7.62 \pm 1.64) \mu \mathrm{mol} \mathrm{Pi} / \mathrm{mg}$ protein per hour. Therefore, no statistically significant changes were found by 
bile acid on the activity of $\mathrm{Na}^{+} / \mathrm{K}^{+}$-ATPase of the subcellular fraction of the colon mucous of patients with IBS.

We observed that the $\mathrm{Ca}^{2+}$-ATPase activity of EPR was ranging from 0.28 to 14.14 . It was equal in average $(5.88 \pm 1.19) \mu \mathrm{mol} \mathrm{Pi} / \mathrm{mg}$ protein per hour. TLC-S adding to the incubation medium resulted in fluctuations its activity from 0.23 to 10.89 and averaged $(6.51 \pm 1.20) \mu \mathrm{mol}$ $\mathrm{Pi} / \mathrm{mg}$ protein per hour. It was found that $\mathrm{Ca}^{2+}$-ATPase activity of PM in control ranged from 4.84 to 15.34 and averaged $(8.86 \pm 1.56) \mu \mathrm{mol} \mathrm{Pi} / \mathrm{mg}$ protein per hour. When TLC-S was added to the incubation medium, the activity rates of this pump ranged from 0.61 to 10.49 and averaged $(6.16 \pm 1.34) \mu \mathrm{mol} \mathrm{Pi} / \mathrm{mg}$ protein per hour.

We found that basal $\mathrm{Mg}^{2+}$-ATPase activity in postmitochondrial subcellular fractions of colon mucous of the patients with IBS ranged from 0.42 to 9.24 , which averaged (6.44 \pm 2.02) $\mu \mathrm{mol} \mathrm{Pi/mg}$ protein per hour. Addition of TLC-S to the incubation medium resulted in fluctuations in the activity of basal $\mathrm{Mg}^{2+}$-ATPase activity in the range from 5.16 to 32.6 and averaged $(23.19 \pm 5.22) \mu \mathrm{mol} \mathrm{Pi} / \mathrm{mg}$ protein per hour.

\section{DISCUSSION}

Influence of TLC-S on $\mathrm{Na}^{+} / \mathrm{K}^{+}$-ATPase activity in postmitochondrial subcellular fraction of colon mucous of the patients with IBS. As $\mathrm{Na}^{+} / \mathrm{K}^{+}$-ATPase plays an important role in electrolyte, water and nutrient transport across the intestinal epithelia, it is expected that the any changes in $\mathrm{Na}^{+} / \mathrm{K}^{+}-\mathrm{AT}$ Pase activity may have a major impact in intestinal function, namely absorption and secretion. It was shown that activities of $\mathrm{Na}^{+} / \mathrm{K}^{+}$-ATPase was increased in children with toddler diarrhea, but $\mathrm{Na}^{+} / \mathrm{K}^{+}$-ATPase activity was reduced in the jejuna mucosa of patients with active celiac disease [12]. So the role of activities of $\mathrm{Na}^{+} / \mathrm{K}^{+}$-ATPasein IBS pathology still unknown. It is consider that perturbed bile acid metabolism plays a causal role in IBS [13]. It is possible to suppose that TLC-S might effect on activity of $\mathrm{Na}^{+} / \mathrm{K}^{+}$-ATPase in postmitochondrial subcellular fraction of colon mucous of the patients with IBS. But we did not found the effect of TLC-S on the activity of $\mathrm{Na}^{+} / \mathrm{K}^{+}$-ATPase of the subcellular fraction of the mucous membrane of the colon in patients with IBS. Our results are agreed with Hafkenscheid, who found that "the taurine derivates TC, TCDC and TDC did not influence or even enhanced the $\mathrm{Na}^{+} / \mathrm{K}^{+}$-ATPase activity " [14].

Influence of TLC-S on total $\mathrm{Ca}^{2+}$-ATPases activity in postmitochondrial subcellularfraction of colon mucous of the patients with IBS. The extracellular $\mathrm{Ca}^{2+}$ influx is balanced by $\mathrm{Ca}^{2+}$ released from the cytosol by both plasma membranes and the internal $\mathrm{Ca}^{2+}$-ATPases. The total $\mathrm{Ca}^{2+}$ -ATPases activity of the subcellular fraction consists of $\mathrm{EPR} \mathrm{Ca}^{2+}$-ATPase and plasma membrane (PM) $\mathrm{Ca}^{2+}$ pump $\mathrm{EPR} \mathrm{Ca}^{2+}$-ATPase play an essential role in the transport of $\mathrm{Ca}^{2+}$ to the EPR to replenish the calcium store, promote folding and protein maturation, lipid and steroid synthesis. It is known that TLC, as well as TLC-S, mobilizes $\mathrm{Ca}^{2+}$ from the intracellular pool. Thus, the main effect of TLC-S is associated with an increase in calcium cells and depletion of calcium stores. Therefore, TLC-S should affect the ac- tivity of $\mathrm{Ca}^{2+}$-ATPases of the subcellular fraction of colon mucous too. But we did not observe the influence of TLC-S on $\mathrm{Ca}^{2+}$-ATPase activity of the subcellular fraction of the colon mucous membrane of patients with IBS.

Influence of TLC-S on basal $\mathrm{Mg}^{2+}$-ATPase activity in postmitochondrial subcellular fractions of colon mucous of the patients with IBS. It should to note that activity of basal $\mathrm{Mg}^{2+}$-ATPase activity is coupled to $\mathrm{H}^{+}$-translocation in PM $[15,16]$ as well as in endosomal fraction [17]. Also in hepatocytes $\mathrm{Mg}^{2+}$-ATPase activity is considered as markers of canalicularmemebrane [18]. $\mathrm{Mg}^{2+}$-activated ATPase of rat colon was studied in mucosa by J.Schreiner and coautors \& Hafkenscheidin [14, 18] and in muscle loyer by Kaplia 2017 [19]. It was shown that all bile acids except cholic acid, taurocholic acid and chenodeoxycholic acid depressed the $\mathrm{Mg}^{2+}$-ATPase activity in rat colon mucosa [14].

We found a statistically significant increasing of the activity of basal $\mathrm{Mg}^{2+}$-ATPase activity in subcellular fraction of colon mucous under the action of TLC-S compared with the control by 3.6 times. The obtained results by the effects of TLC-S are in full agreement with the previously observed the effect of TLC-S on the activity of basal $\mathrm{Mg}^{2+}$-ATPase activity in the subcellular fraction of rat liver [20].

It has been suggested that activation of basal $\mathrm{Mg}^{2+}$-ATPase under the action of TLC-S may indicates to the role of the endo-lysosomal system, the so-called acid store of colon mucous of the patients in developing of pathology IBS.

\section{CONCLUSIONS}

TLC-S $(50 \mu \mathrm{M})$ increased basal $\mathrm{Mg}^{2+}$-ATPase in the postmitochondrial fraction of colon mucous of the patients with overweight and IBS, but had no effect on $\mathrm{Na}+$ / $\mathrm{K}+$-ATPase and total $\mathrm{Ca}^{2+}$-ATPases activity.

\section{REFERENCES}

1. Bychkov M.A., Ferents I.M. Features of the course of irritable bowel syndrome in patients with excess body weight. WiadLek. 2018; 71(3 pt 2):688-690.

2. Mishchuk V.G., Grigoruk G.V. Types of eating behavior and serotonin levels in patients with irritable bowel syndrome and constipation on the background of obesity. J. Clin. Exp. Med. Res. 2018;6(1):176-182.

3. Larussa T, Rossi M, Surari E et al. Use of Complementary and Alternative Medicine by Patients with Irritable Bowel Syndrome According to the Roma IV Criteria: A Single-Center Italian Survey. Medicina (Kaunas). 2019; 55(2):46. doi: 10.3390.

4. Moayyedi P, Mearin F, Azpirioz F, Andersen V. Irritable bowel syndrome diagnosis and management: A simplited algorithm for clinical practice. United European Gastroenterology Journal. 2017; 5(6):773-88.

5. Lacy BE, Patel NK. Rome Criteria and a Diagnostic Approach to irritable Bowel Syndrome. J. Clin Med, 2017; 6(11):99.

6. StepanovYu.M., Budzakl.Ya., Klenina I.A. Short-chain fatty acids: the role in the development of irritable bowel syndrome. Gastroenterologia. 2019;53(1):49-53.

7. Vijayvargiya P., Busciglio I., Burton D. Bile Acid Deficiency in Subgroup of Patients With Irritable Bowel Syndrome With Constipation Based on Biomarkers in Serum and Fecal Samples. ClinGastroenterolHepatol. 2018; 16(4): 522-527. 
8. Bychkova S, Hreniuh V. Activity of ATPases in postmitochondrial fraction of lymphoma NK/Ly cells under bafilomicine and NAADP presence mitochondria. Studia Biologica.2016;9(2):31-38.

9. Hreniukh V, Bychkova S, Kulachkovsky 0, Babsky A Effect of bafilomycin and NAADP on membraneassociated ATPases and respiration of isolated mitochondria of the murine Nemeth-Kellner lymphoma. Cell biochemistry and function. 2016; 34 (8): 579-587.

10. Lowry 0.H., Rosebrough N.J., Farr A.L. et al. Protein measurement with the folin phenol reagent. J. Biol. Chem. 1951; 193:265-275.

11. Fiske C, Subbarow Y. The colorimetric determination of phosphorus. JBiol Chem. 1925;66:375-400.

12. Tripp J,Muller D, Harries J Mucosal (Na+-K+)-ATPase and Adenylate Cyclase Activities in Children with Toddler Diarrhea and the Postenteritis Syndrome. Pediat. Res. 1980; 14: 1382-1386.

13. Hofmann A.F. Causal Role of Bile Acids in Irritable Bowel SyndromeConstipation. Clinical Gastroenterology and Hepatology. 2019; 17 (1):213-214.

14. Hafkenscheid JCM Influence of bile acids on the ( $\mathrm{Na}+-\mathrm{K}+)$-activated-and Mg2+-activated ATPase of rat colon.Pflügers Archiv.1977;369(3):203-206.

15. Kosterin SO, Veklich TO, Prylutsky YI. Kinetic interpretation of pH dependence of enzymatic activity of "basal" Mg2+-ATPase of sarcolemma of smooth muscle. Ukr. biochem. journal. 2005; 77 (6): 37-45.

16. Luu-The V., Goffeau A., Thinès-Sempoux D. Rat liver plasma membrane $\mathrm{Ca} 2+-$ or $\mathrm{Mg} 2+$-activated ATPase. Evidence for proton movement in reconstituted vesicles. Biochim. Biophys. Acta. 1987; 904 (2):251-258.

17. Saermark T., Flint N., Evans W. H. Hepatic endosome fractions contain an ATP-driven proton pump. Biochem. J. 1985; 225: 51-58.

18. Schreiner J., Nell G., Loeschke K. Effect of Diphenolic Laxatives on Na+$\mathrm{K}+$-activated ATPase and Cyclic Nucleotide Content of Rat Colon Mucosa in Vivo. NaunynSchmiedebergs Arch Pharmacol. 1980; 313 (3): 249-55.

19. Kaplia A.A. Different sensitivity of $\mathrm{Na}+, \mathrm{K}+-$-ATPase and Mg2+-ATPase to ethanol and arachidonic acid in rat colon smooth muscle under pretreatment of cellular membranes with Ds-Na. Ukr. Biochem. J. 2017; 89 (2): 70-77.
20. Bychkova S.Influence of taurolithocholate 3-sulphate on activity of $\mathrm{Na}+, \mathrm{K}+-$ ATPase, $\mathrm{Ca} 2+-$ ATPase and basal Mg2+-ATPase in rat liver subcellular fraction//Visnyk of the Lviv University. Series Biology. 2016; 72: 194-201.

Fragment of the research work: "Pathology of the respiratory, cardiovascular and digestive systems in patients with diabetes and obesity: features of pathogenesis, diagnosis and treatment”. №: IH.09.0001.16

\section{ORCID and contributionship:}

Iryna M. Ferents - 0000-0001-5032-2698 ${ }^{B C D}$

Solomiia V. Bychkova - 0000-0002-5107-3352 ${ }^{\mathrm{B}}$

Mykola A. Bychkov - 0000-0001-6620-1751 ${ }^{\text {A, F }}$

\section{Conflict of interest:}

The Authors declare no conflict of interest.

\section{CORRESPONDING AUTHOR Mykola A. Bychkov}

Str. Yaroslava Mudrogo, 22/5, 79016, Lviv, Ukraine

tel: +3805603753044

e-mail:koloboc2000@gmail.com

Received: 17.01 .2020

Accepted: 05.03 .2020

A - Work concept and design, B - Data collection and analysis, C - Responsibility for statistical analysis,

D-Writing the article, $\mathbf{E}$-Critical review, $\mathbf{F}$ - Final approval of the article 